\title{
ILLUSTRATIVE PRESENTATION IN FORMATION OF ESL STUDENTS' LEXICAL SKILLS
}

\author{
APRESENTAÇÃO ILUSTRATIVA NA FORMAÇÃO DAS HABILIDADES LEXICAIS \\ DOS ESTUDANTES DE ISL
}

\author{
PRESENTACIÓN ILUSTRATIVA EN FORMACIÓN DE HABILIDADES LÉXICAS DE \\ LOS ESTUDIANTES DE ESL
}

\author{
Shangareev Mustafa MANSUROVICH ${ }^{1}$ \\ Anna Anatolyevna KARIMOVA ${ }^{2}$ \\ Oxana Vladimirovna KHASANOVA ${ }^{3}$ \\ Svetlana Viktorovna SHUSTOVA ${ }^{4}$
}

\begin{abstract}
The article is devoted to the problems of forming and developing lexical skills by modern multimedia means of visualization in the ESL classroom. Modern technologies have led to new possibilities to integrate multimedia tools and means of visualization in the ESL classroom. The aim of this paper is to analyze the current ESL coursebooks and coursebook supplements and give recommendations to teachers on how to use the sufficient range of means of visualization effectively. As a part of research, different types of questionnaires were handed to teachers and first-year students of Bachelor's Program "Pedagogical Education (double major) and Second Foreign language" (5 years, full time) of Kazan State University. After this, a set of classes was organized for two groups of first-year students. The outcomes have been measured with qualitative and quantitative methods. The results show that the teachers do not use means of visualization and are not ready to make them into an integral part of everyday lessons due to time management issues, lack of methodical ways of organization of educational process. Due to these results, it can be resumed that using multimedia means of visualization as tools in the ESL classroom is highly beneficial for students and enhanced the learning process.
\end{abstract}

KEYWORDS: ESL students. Lexical skills. Illustrative presentation. Visual aids. Means of visualization.

\footnotetext{
${ }^{1}$ Kazan Federal University (KPFU), Kazan - Russia. Assistant at the Department of Language and Intercultural Communication, Institute of Philology and Intercultural Communication. ORCID: https://orcid.org/0000-00024601-8105. E-mail: refolit@gmail.com

${ }^{2}$ Kazan Federal University (KPFU), Kazan - Russia. Associate Professor of the Department of Theory and Practice of Teaching Foreign Languages, Institute of Philology and Intercultural Communication. Candidate of Pedagogy. ORCID: https://orcid.org/0000-0002-0908-8243. E-mail: an.carimova2012@yandex.ru

${ }^{3}$ Kazan Federal University (KPFU), Kazan - Russia. Associate Professor of the Department of Theory and Practice of Teaching Foreign Languages, Institute of Philology and Intercultural Communication. Candidate of Pedagogy. ORCID: https://orcid.org/0000-0002-4979-3238. E-mail: khasanova oxana@rambler.ru

${ }^{4}$ Perm State National Research University (PSU), Perm - Russia. Professor of the Department of Linguistics and Translation of the Faculty of Modern Foreign Languages and Literatures and Professor of the Department of Theoretical and Applied Linguistics, Philological Faculty. Doctor of Philology. ORCID: https://orcid.org/00000002-8318-7864. E-mail: lanaschust@mail.ru
}

RPGE- Revista on line de Política e Gestão Educacional, Araraquara, v. 25, n. esp. 1, p. 462-471, mar. $2021 . \quad$ e-ISSN:1519-9029 
RESUMO: $O$ artigo é dedicado aos problemas de formação e desenvolvimento de habilidades léxicas por meios modernos de visualização multimídia na sala de aula de ISL. As tecnologias modernas têm levado a novas possibilidades de integrar ferramentas multimídia e meios de visualização na sala de aula de ISL. O objetivo deste artigo é analisar os atuais manuais e suplementos dos manuais de ISL e dar recomendações aos professores sobre como usar uma gama suficiente de meios de visualização de forma eficaz. Como parte da pesquisa, diferentes tipos de questionários foram entregues a professores e alunos do primeiro ano do Programa de Bacharelado "Educação Pedagógica (dupla especialização) e Segunda Língua Estrangeira" (5 anos, tempo integral) da Universidade do Estado de Kazan. Depois disso, um conjunto de aulas foi organizado para dois grupos de alunos do primeiro ano. Os resultados foram medidos com métodos qualitativos e quantitativos. Os resultados mostram que os professores não utilizam meios de visualização e não estão prontos para torná-los parte integrante das aulas diárias, devido a questões de gerenciamento de tempo e falta de formas metódicas de organização do processo educacional. Devido a estes resultados, pode-se presumir que o uso de meios de visualização multimídia como ferramentas na sala de aula de ISL é altamente benéfico para os alunos e melhora o processo de aprendizagem.

PALAVRAS-CHAVE: Estudantes de ESL. Habilidades lexicais. Apresentação ilustrativa. Auxílios visuais. Meios de visualização.

RESUMEN: El artículo está dedicado a los problemas de formación y desarrollo de habilidades léxicas mediante medios de visualización multimedia modernos en el aula de ESL. Las tecnologías modernas han dado lugar a nuevas posibilidades para integrar herramientas multimedia y medios de visualización en el aula de ESL. El objetivo de este artículo es analizar los libros de texto y suplementos de libros de texto actuales de ESL y ofrecer recomendaciones a los profesores sobre cómo utilizar la gama suficiente de medios de visualización de manera eficaz. Como parte de la investigación, se entregaron diferentes tipos de cuestionarios a los profesores y estudiantes de primer año del Programa de Licenciatura "Educación Pedagógica (doble especialización) y Segunda Lengua Extranjera" (5 años, tiempo completo) de la Universidad Estatal de Kazán. Posteriormente, se organizó un conjunto de clases para dos grupos de alumnos de primer año. Los resultados se han medido con métodos cualitativos y cuantitativos. Los resultados muestran que los profesores no utilizan medios de visualización y no están preparados para convertirlos en parte integral de las lecciones diarias debido a problemas de gestión del tiempo, falta de formas metódicas de organización del proceso educativo. Debido a estos resultados se puede resumir que el uso de medios de visualización multimedia como herramientas en el aula de ESL es altamente beneficioso para los estudiantes y mejora el proceso de aprendizaje.

PALABRAS CLAVE: Estudiantes de ESL. Habilidades léxicas. Presentación ilustrativa. Ayudas visuales. Medios de visualización.

\section{Introduction}

Recently, the development of information and communication technologies has significantly affected not only education but has also changed the process of perception of 
information by modern students. While explaining a new studying material, one can use presentations created in the PowerPoint program, which allow the speaker to convey visually the material to students, increasing their learning level. This makes students' memorization easier, activates their perception, helps to increase attention, and reduces tiredness (ABDRAFIKOVA; AKHMADULLINA; YARMAKEEV, 2015). The introduction of such concepts as "clip thinking" and "visual culture" in foreign language teaching demonstrates the current tendency to shift towards the visual perception of information. In this case, it becomes necessary to expand the range of visualization tools from images, illustrations, educational posters, toys, models to illustrative presentations such as video podcasts, internet platforms, computer programs, educational applications, infographics. According to Ahrapova A. Kh at $\mathrm{Al}$, digital tools and approaches should be introduced in the classrooms as they are getting deeply integrated into our everyday lives from day to day; therefore, digitalisation is one of the key driving forces of competitiveness, growth and welfare (SHARAFIEVA et al., 2019).

Wide variation of modern multimedia means of visualization involves not only new opportunities for their implementation, but also puts forward new requirements for the modern teacher and the actual educational and methodological support of the English language learning process.

The relevance of the study is primarily due to the requirements of the second generation of the Russian Federal Standards in Education (RFSE), according to which the study of a foreign language is aimed at the formation and development of communicative competence and but also the formation of digital communication competence.

Effective process of teaching foreign language vocabulary and formation and development of lexical skills means the increase of the degree of lexical variability that allows students not only to formulate their own thoughts in the framework of foreign language communication, but also significantly expands the range of topics for communication in a foreign language. However, there is an obvious contradiction between the potentially effective means of visualization and the insufficient level of their implementation in educational process of teaching languages.

Thus, the problem of the research is the development of methodology of effective integration of multimedia tools and modern multimedia means of visualization in the process of formation of students' lexical skills in teaching foreign languages. 


\section{Methods}

According to the modern researches, it is the visual channel of a person that receives more than $80 \%$ of all information coming from the outside world (FAHRUTDINOV; FAHRUTDINOVA; ABSATOVA, 2018).With the advent of new media resources, there was a so-called visual transition, in which the former focus of attention and full perception of information within the text medium with minimal support in the form of images and sound shifted towards a complex multi-component visual image (video, special effects, 3D image and surround sound). This phenomenon has led to several changes in the psychophysiological features of modern students. As we have moved on to the emotive clip art thinking, the attention has ceased to focus on long texts, which confirms the relevance of the principle of visibility in the framework of modern education.

Modern RFSE consider these changes, putting forward new requirements for the educational process in the form of innovative technologies and approaches to the implementation of the principle of illustrative clarity. As part of the English language training, this means achieving a high level of foreign language communicative competence. A special role here is played by the process of formation and development of lexical skills of students by modern media multimedia means of visualization. Classical methods of teaching foreign language involves the use of visual means of presentation in the formation of lexical skills, such as creating incentive to apply and consolidate the studied vocabulary, speech situation or conditionally-vocal task, in which visual presentation helps to realize the educational and developmental goals in learning a foreign language; it brought a sense of beauty, develop aesthetic perception and taste, formed visual competence. In addition, the use of bright colorful relevant illustrative material increases interest in the subject, relieves stress, creates a situation of success. It should be considered that color matching plays a big role in the perception and committing information into long-term memory. According to Thomas Sanoki and Noah Sulman (VALIAKHMETOVA; AKHMADULLINA; PIMENOVA, 2017) the best memory is promoted by harmonious, combined colors, the total number of which does not exceed contrasting colors (opposite colors on the color wheel). For example, blue-orange, red - green, purple - yellow, affect the concentration and improve it, as in their essence are irritants. However, long-term exposure to contrast saturated colors can lead to rapid fatigue. Thus, with the help of colors, we can manipulate the attention of students, highlighting the contrasting colors of the word, you can direct your attention to the new vocabulary, and more muted and harmonious contribute to their better memory. However, the organization of visual 
material should not overload the audience with excessive contrast, it is necessary to leave room for rest to the eyes and highlight the important, determining the central element of focus.

When implementing modern media multimedia means of visualization, it generally involves independent work of students on their projects, for example, summaries based on the infographic, intellectual theme maps (mind map technology); enhances motivation to learn a foreign language. Thus, the use of memes can become a bridge between a low-motivated student and, in fact, the need to learn a foreign language, because in this case, he will understand the meaning of the visual image in the perception of foreign-language sociocultural phenomenon, and this particular image is not explained in the educational process, but is the result of visual semantics and formed foreign-language communicative competence in general.

Nowadays there are a lot of textbooks at the disposal of ESL teachers to work in the classroom, but they do not always satisfy the learners' needs and goals that is why most of the ESP colleagues use their in-house materials in ESL teaching tailored for the specific purposes and needs of their students (VERBITSKY, 2004). The analysis of current ESL coursebooks and coursebook supplements showed that they do not reflect modern approaches to the understanding of the process of visualization, do not reveal the potential of graphic and illustrative visualization in the formation and development of lexical skills. It should also be noted that a large amount of visual material in the English language textbook does not involve structured lexical exercises associated with this material. However, there might be used additional exercises with the help of modern multimedia means of visualization: mind maps, word clouds, digital painting, infographics, e-comics and so on. An important clarification in this case is that the effectiveness that requires additional time from the teacher, professional information competence. The study also included a teachers' survey and students' questionnaires on such criteria as the current ESL coursebooks and coursebook supplements' design in general, amount of visual means used.

\section{Results and discussion}

The results of the survey and questionnaires showed that more than $80 \%$ of respondents are engaged on the ESL coursebook "Speak out" (DENISENKOVA, 2020), which indicates primarily its high prevalence compared to its competitors in the market. However, less than $35 \%$ of English teachers surveyed mentioned it when answering the 
question of which coursebook, they prefer. The comparative analysis showed that "Language Leader" (MEREKKEEVNA et al., 2018), is more suitable for the curriculum and standard requirements of Bachelor's Program "Pedagogical Education (double major) and Second Foreign language " (5 years, full time) of Kazan State University.

Despite this, more than half of the surveyed students believe that these modern coursebooks have a sufficient level of clarity, which helps them understand the meaning of words.

Diagram 1 - Do you think that there are enough pictures and illustrations in textbooks that reveal the meanings of words?

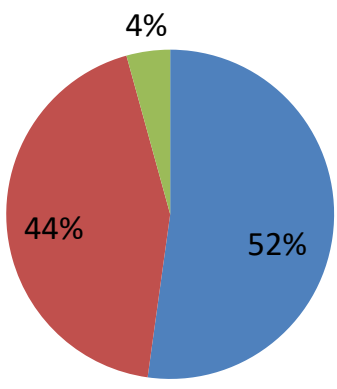

yes, just enough, the visual support helps me to reveal the meaning of some words

there are pictures, but they do not help me to understand what it is all about

there are almost no pictures and illustrations

Source: Developed by the authors

Next, we provided for estimating respondents two spread coursebooks - "Speak Out" and "Language Leader" and compared the topic "Jobs/Work", without specifying what coursebook was selected to avoid bias, and asked the respondents which of the two options reveals the topic more successfully from the point of modern multimedia means of visualization. This question was aimed at identifying the preferences of illustrative means, since both options differed radically: the first coursebook illustrated not only the phenomenon itself, but also included a background for it in different forms including video extracts and podcasts as one component in electronic version of the coursebook, correlating with the topic of the text - "Jobs" aimed at speaking mostly. The second coursebook does not stand out for special brightness and illustrative, also offering the students concise photos and illustrations, video extracts and multimedia exercises in E-text format but aimed at linguistic analysis of the language samples (reading, listening, writing and speaking) so that lexical skills are in focus. As a result, more than $80 \%$ of respondents felt that "Speak Out" reveals this topic 
better, which means the design of the textbook is generally more functional and colorful than its opponent though "Language Leader" is more effective in forming and development of lexical skills .

The next step in the evaluation was the two variants of lexical tasks from the coursebooks "Speak Out" and "Language Leader" in order to identify the effectiveness of the tools implemented and the graphical and illustrative clarity from the point of view of work with the lexical minimum. The results of the survey showed that in general, the visibility of the textbook "Speak Out" is at a high level, however, its use from the standpoint of the formation and development of lexical skills is not effective enough. Thus, about $73 \%$ of respondents chose exercises from "Language Leader" which were quite illustrative, concise, and directly related to the vocabulary on the topic. These findings suggest primarily that "Speak Out" requires additional systematization of visualization tools in the formation and development of lexical skills.

\section{Summary}

The theoretical generalization of pedagogical experience and analysis of modern research on modern multimedia means of visualization, as well as the results of the research, allowed to make some recommendations on the effective use of modern multimedia means of visualization in the process of formation and development of lexical skills in foreign language acquisition. The aim of the teacher of a foreign language is the formation of knowledge, skills and habits necessary for the work on the special literature in a foreign language; study of specialized vocabulary, terminology, abbreviations adopted in the foreign literature; organization of communication activities in a foreign language (ABDRAFIKOVA et al., 2020).

Awareness and understanding of the basics of the visual component of graphic and illustrative tools can help to remove the main difficulties in their implementation in the educational process. On the other hand, this will reduce the fatigue of students, because they do not have to make additional efforts to analyze information. Thus, the teacher needs a systematic study of modern multimedia means of visualization in the framework of training or specialized courses.

It is important to understand that about $90 \%$ of what people see, starting from primary school age, correlates with previous life experiences. Accumulating knowledge takes place on the basis of the information already known (SERGEEV, 2004). Introduction of topical 
podcasts in educational process, online communication in the framework of the group work will allow not only to plunge into the socio-cultural environment of the language, but also to share their life experiences with peers.

Depending on the age and learning goals, you can choose such types of visualization as drawing, creating intelligence maps or summaries with the use of infographics. This helps to consolidate the studied set of words in practice by involving all types of speech activity, including mechanisms of fine motor skills.

The next set of recommendations is closely related to pedagogical ethics and principles of health saving. When preparing visual material should consider the age of students, their interests, level of language proficiency. The content of visual aids should not include material that harms the mental health of students, should not contradict moral and ethical principles, and therefore should not promote violence and aggressive behavior.

The modern multimedia means of visualization can be useful and make the process of language learning more effective only in the case of a systematic approach to the organization of the lesson, otherwise all the content essence is lost, and all the materials used simply serve as a reference visualization. All tasks should be thought over in advance, have a sequence and relationship between them, all instructions should be clearly formulated, they should correspond to the goals and objectives of the lesson. The demonstration of modern multimedia means of visualization should be organized in such a way that all students are able to see it clearly regardless of their location in the classroom. The teacher is required to check in advance and make sure that the images are well read, bright enough, but moderately contrast.

\section{Conclusions}

Current ESL coursebook and coursebook supplements are one of the main and basic means of training, implementing the requirements of the new generation of RFSE. When multimedia is used it helps the students in developing mental models and connect to the new knowledge domain. They are better able to visualize the activities in the knowledge domain and learn from them ${ }^{5}$.

At this stage of development of ESL coursebook and coursebook supplements there is a trend that reflects the intensification of the role of the English language in modern society; this is manifested in the shift of focus from imitation exercises to language analysis, both in

${ }^{5}$ Available: http://www.edu.ru. Access: 10 dec. 2020. 
the topics under consideration, and in the external attractiveness of the design of the components of ESL coursebook. Unlike their predecessors, new textbooks, workbooks, and other components of ESL coursebook have colorful décor, a large amount of visual material in the form of graphs, tables, pictures, photos. Visual clarity in the form of modern multimedia means of visualization is found when entering the topic vocabulary and is a direct way to acquiring of word meaning. However, the results of our research show that not all ESL coursebooks fully realize the modern media visual aids at full capacity in the formation and development of lexical skills. Thus, we have concluded that the introduction of additional exercises using modern multimedia means of visualization could fill the gaps of the ESL coursebook, improve the efficiency of the language learning and the motivation of students to learn English.

ACKNOWLEDGEMENTS: The work is performed according to the Russian Government Program of Competitive Growth of Kazan Federal University.

\section{REFERENCES}

ABDRAFIKOVA, A. R.; AKHMADULLINA, R. M.; YARMAKEEV, I. E. Formation of the communicative competence in students future pedagogues for working with gifted pupils. Social Sciences, Pakistan, v. 10, n. 7, p. 1817-1821, 2015.

ABDRAFIKOVA, A. R.; AKHMADULLINA, R. M.; YARMAKEEV, I. E.; PIMENOVA, T. S.; VALIAKHMETOVA, N. Five Easy Steps to Successfully Teach Your Course in English. In: INTERNATIONAL TECHNOLOGY, EDUCATION AND DEVELOPMENT CONFERENCE, 14., 2020, Valencia. Proceedings [...]. Valencia, Spain: INTED2020, 2020. v. 1. p. 3680-3688.

DENISENKOVA, N. S. Exploring first graders' learning motivation in different educational environments. Psychological Science and Education, v. 25, n. 1, p. 5-15, 2020.

FAHRUTDINOV, R.; FAHRUTDINOVA, R.; ABSATOVA, M. An independent work of students in the process of professional training of future teachers of foreign language in the educational space of the higher educational institution. National Academy of Managerial Staff of Culture and Arts Herald, n. 3, 2018.

MEREKKEEVNA, E. B.; FAHRUTDINOVA, R. A.; FAHRUTDINOV, R. R.; SHAKIROVA, A. Formación de estudiantes en tecnología del crédito en educación de Kazajstán. Orbis: Revista de Ciencias Humanas, v. 14, n. 41, p. 87-94, 2018.

RUSSIA. State educational standard of higher education [Electronic resource]. Available: http://www.edu.ru. Access: 10 dec. 2020. 
SERGEEV, I. S. Fundamentals of pedagogical activity: textbook. New knowledge, n. 4, p. 56-58, 2004.

SHARAFIEVA, A. M.; YARMAKEEV, I. E.; PIMENOVA, T. S.; ABDRAFIKOVA, A. R.; TREGUBOVA, T. M. Modeling dialogues in FL class. International Journal of Higher Education, v. 8, n. 7, p. 62-68, 2019.

VALIAKHMETOVA, N.; AKHMADULLINA, R.; PIMENOVA, T. Ethno-pedagogy as a means of ethnic identity formation of pre-service teachers in Russia. Social Sciences and Humanities, v. 1, p. 387-392, 2017.

VERBITSKY, A. A. Research center of problems quality of training. In: Competence approach and theory of context training: materials for the fourth meeting of the methodological seminar. 2004. p.84.

\section{How to reference this article}

MANSUROVICH, S. M.; KARIMOVA, A. A.; KHASANOVA, O. V.; SHUSTOVA, S. V. Illustrative presentation in formation of ESL students' lexical skills. Revista on line de Política e Gestão Educacional, Araraquara, v. 25, n. esp. 1, p. 462-471, mar. 2021. eISSN:1519-9029. DOI: https://doi.org/10.22633/rpge.v25iesp.1.14983

Submitted: 06/11/2020

Required revisions: 18/01/2021

Approved: $23 / 02 / 221$

Published: 01/03/2021 